\title{
Drivers of Entrepreneurial Intention Among Students of The University of The Gambia
}

\author{
Musa Manneh, Ismaila Bojang, Lamin B. Ceesay, and Sama Jawneh
}

\begin{abstract}
This paper examined the drivers of entrepreneurial intention among students of the University of the Gambia. Various theories were adopted in the past to study entrepreneurial intentions among university going students. Building on the relevant literature on entrepreneurship models, this research examines student intention to engage in entrepreneurial ventures in the Gambia. In line with several (prior) research, our results confirm the important role of the business climate, entrepreneurial attitude and subjective norms on students' intention to engage in entrepreneurial ventures. These results contribute to the literature by demonstrating the peculiar environment and segment of the population (the youth) that is emerging in the field of entrepreneurship, and the significance of entrepreneurship education. Our results provide implication for the government, policymakers, and educational institutions. The agenda for future research have also been discussed.
\end{abstract}

Index Terms-Entrepreneurship, Intentions, Gambia, University students, business venture.

\section{INTRODUCTION}

An entrepreneurial venture is a growing phenomenon as a source of economic growth, innovation and job creation. These benefits lead to a surge in entrepreneurship awareness among academics, politicians and corporate institutions. For emerging economies, entrepreneurship education is a key driver of economic performance [1], [2]. Entrepreneurship training and education have intensified the benefits of economic and social benefits associated with the proliferation of entrepreneurship practice and continuous training. Students are critical aspects of entrepreneurial training. For example, entrepreneurial education and training programs in The Gambia continue to receive noticeable gains over the last few years.

Both in developed and developing countries, citizens are facing challenges, including a potential lack of opportunities to engage in their economies productively [2]. Not only do people face increasing uncertainty in finding employment in the formal labour market, they are also experiencing important mismatches between the skills they possess and the demands of employers. As a popular claim in the entrepreneurship field, people posit that "it is rather pleasant being a boss but to self, work on your schedule, and make money doing something that you're skilled at or passionate about." Millions of people around the world are living that dream and running their own business. One way of fulfilling this desire is the creation of entrepreneurial ventures (e.g. [3], [4].

Despite the growing interest of policymakers on entrepreneurship potentials, the limited insights into motivations and skills of university students remain highly

Published on June 13, 2020

Lamin B. Ceesay, University of the Gambia, Gambia.

(corresponding e-mail: lbceesay@utg.edu.gm) limited. This limitation affects the prioritization of entrepreneurship training and education to the most vibrant population of the country (the youth and women). Thus, our paper investigates using common entrepreneurial models to inform researchers and policymakers about the critical drivers of at the University of The Gambia (henceforth, UTG) students' intention to engage in entrepreneurship. This study uses a survey method on students enrolled in various programs at the UTG. The new entrepreneurship policy of The Gambia highly encourages university students to venture into entrepreneurial businesses.

Leveraging the Theory of Planned Behaviour applies to any behaviour that requires a certain amount of planning [5], [6]. The model has been used in several settings, example, in forecasting behaviour and intentions in various fields such as health care (weight loss, quitting smoking), safety (seat belt usage), marketing (coupon usage) and career choice. The Theory of Plan Behaviour model (TPB) is the highest recipient of empirical research than Entrepreneurial Event Model (EEM) and Entrepreneurial Intention Model (EIM). The deficiency of both EEM and EIM models is that they do not show the existence of facts on subjective norms [5], [6]. The literature also added that both EEM and EIM attitude in venture creation is part of the wider concept of personal and social level factors. The combination of these factors influences entrepreneurship practice in terms of desirability or willingness to engage in venture formation [5], [22]. The TPB model, on the other hand, is associated with the entrepreneurial behaviour at the personal level, while the impact of social level factors influences entrepreneurial attitude. This distinction between the two factors is more robust on the behavioural intention than EIM and EEM models [2], [5], [7], [8]. In entrepreneurship front, scholars observe the theory of planned behaviour according to the entrepreneurial behavior and intention [9], [10], [11], [12], [8], [13], [14].

The research is thus organized as follows: the first section is the introduction presented above, followed by the second section, on theoretical background and the hypothesis development. The third section is the research method, which is followed by a section fourth section that discusses the research findings of the study. The final section illustrates the conclusion, research implication and future research agenda.

\section{THEORETICAL BACKGROUND AND HYPOTHESIS \\ A. Theory and motivation of intention in entrepreneurial studies}

The concept of intentionality can be traced as far back as during the period of Socrates, who investigated people's evil intention behaviour [15]. The authors add that intention, in general, describes a belief that a person performs certain behaviour. In entrepreneurship front, there are several definitions of entrepreneurial intention, but the most 
comprehensive one used by scholars describe entrepreneurial intention as "a self-acknowledged conviction by a person that they intend to set up a new business venture and consciously plan to do so at some point in the future" [16] (p. 676). Further, other scholars illustrate that behavioural intention revolves around an individual's strong desire to try and do something in the future (e.g., [5] (p. 132)).

Many scholars try to sought answers to the question "why some people become entrepreneurs? (e.g., [17], [18]). Out of these studies, a significant number of scholars focus on investigating the difference between entrepreneurial and non-entrepreneurial intentions. However, these researches do not answer the question of entrepreneurial intention simply because people may differ in thinking and motivational intentions but do not essentially mean that such motivations always lead them to choose one path or the other [19]. Then, entrepreneurial intention researchers should rather focus on venture creation to answer this question. One key approach of defining and understanding entrepreneurial intention plus motivation is to study the allinclusive process of venture creation. This said process is barely possible because of its high time-consuming nature. This high time consumption may also include a substantial time interim between idea creation and the actual formation of the venture [20], [21].

Furthermore, conducting entrepreneurship research by interviewing current entrepreneurs equally lead to survivalbias, for the reason that the entrepreneurial ventures that are mostly included in the study are those successfully initiated and still maintain ventures [22], [23a], [23b]. Krueger \& Carsrud [24] argued that entrepreneurial intentions studies should incorporate prospective analyses applications in looking at people who could or will become entrepreneurs in times earlier to venture formation. Scholars add added that prospective analyses applications may aid the forecast of behaviour and description of the principal motivation [25],[45]. This is mostly true for unpredictable phenomena of venture creation. This process can also be analyzed without perceiving the phenomena that occur in the venture creation, thus intentional studies are the best predictors of behaviour and its variables [24].

\section{B. Applicable models and hypotheses}

The entrepreneurial intention model [26] and its revised propositions [27] hinge on the cognitive theory that describes an individual's behaviour as a "state of mind directing a person's attention toward a specific object or path to achieve a goal" [26], (p. 4420). Bird propounded this model in an entrepreneurial venture formation and management. Thus, the entrepreneurial intention could be influenced by the degree of personal and contextual factors. The authors argue that personal traits such as previous business experiences, abilities and personalities as well as the open environmental factors are all-inclusive of the model [26]. Moreover, the role of government de-regulation is critical aspects of contextual factors influencing entrepreneurial intention and implementation of business ideas.

The revised proposition of the entrepreneurial intention model [27] recognizes the importance of self-efficacy construct. The researcher further argues that the selfefficacy construct comprises individual capability for goal achievement through rational choice and actions [28].
Therefore, the entrepreneurial intention is an antecedent and a determinant of entrepreneurial behaviour [27]. The investigation of Ajzen [34] added that this causal relationship is generally strong when behaviours are not influenced by a problem of control; hence intentions can very much predict actions. A similar a study by Autio and colleagues [10] shows a positive effect in many situations. Other studies, however, report that intention-behaviour links are superior to direct attitude-behaviour links (e.g., [24], [30]). Thus, intentions are an acceptable predictor of behaviour and intention models can't do without a behavioural variable.

Leveraging the theory of planned behaviour model [5], the theory of reasoned action [6], intention studies are based on three attitudinal dimensions namely, attitude toward the behaviour, subjective norm and perceived behavioural control. Following these notable scholars, planned behaviour model is an appropriate model for explaining individual planned behaviour such as the engagement in entrepreneurship venture (e.g., [5], [31]). The attitude toward the behaviour denotes to the point at which a person has a favorable or unfavorable evaluation of behaviour. This factor looks at the beliefs about the possible outcomes of the behaviour (i.e., behavioural beliefs). For example, a person who believes that it is beneficial to perform a given behaviour will have a positive attitude toward that behaviour; otherwise, will hold a negative attitude [5]. Subjective norm described in the model as social pressures perceived by individuals to perform or not to perform the behaviour. It recounts to the beliefs that other people are either encourage or discourage to carry out a behaviour. A person is possible going to perform a behaviour if his or her motivator conform or agree to go in for it. On the other hand, a person will suffer a subjective norm that forces him or her to avoid performing the behaviour. Perceived behavioural control refers to the judgement of easiness or difficulty in performing a behaviour. It recounts to the beliefs about the availability of supports and resources as well as barriers to performing an entrepreneurial behaviour (control beliefs).

Using the planned behaviour model [5], a theory of reasoned action [6] and the entrepreneurial intention model [26], this research examines key drivers of entrepreneurial intention among students. Thus, to address this research problem, four hypotheses are proposed:

H1. Perceived behavioural factors affect students' entrepreneurial intention.

H2. Subjective norms of students associated with entrepreneurial ventures affect their intention to engage in entrepreneurship.

H3. Students' perception of entrepreneurial attitude affects their intention to engage in entrepreneurship.

H4. The existing business climate of a country affects students' intentions to engage in entrepreneurship venture. 


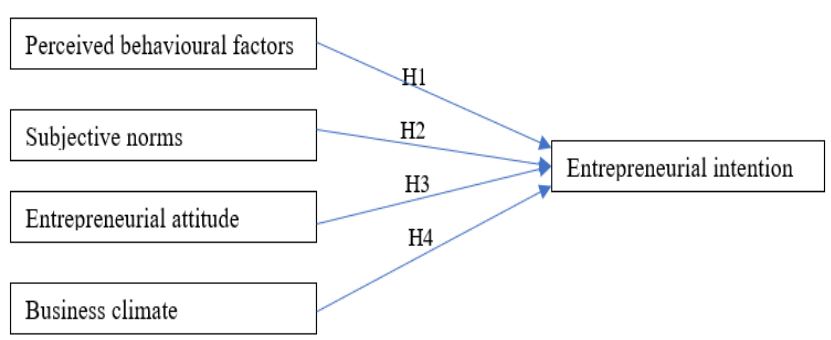

Fig 1. A Research Framework

\section{METHODOLOGY}

To observe the entrepreneurial intention of students of the University of the Gambia, this research uses a crosssection of the student population. The objective of this method is to elicit opinion on the student population with regards to their current and future intention to engage in entrepreneurial ventures. The quantitative method adopted by this study is thus positive, which helps to confirm or rejects the hypothesis of the research by this study. We use IBM SPSS statistical software for the analysis of the results of this research.

\section{A. Sampling}

Following several studies, respondents were selected based on a convenient sample of the students who participate in this research (e.g., [32], [33]). The survey takes about ten minutes to complete. The first section of the questionnaire addresses the key biographic data of respondents, such as respondents' gender, age brackets, and the current level of education. The last section observes the thematic issues of the research that comprise of the hypothetical framework of the study.

Respondents were drawn from the current student population of the university enrolled in various academic programs which includes university access program for high school graduates, professional diploma programs, undergraduate (bachelors), graduate (masters) programs across various departments and schools of the UTG. This research adopts the empirical, primary data collection method. We leveraged the online survey technique to elicit responses according to a systematic process. As lecturers of the University, a link of the survey questionnaire was sent out to students via their email addresses and Facebook messenger, as well as Whatsapp contacts. A total of one hundred and eighty-nine (189) students participated in this research. However, only one incomplete questionnaire has been received.

\section{B. Explanatory analysis of reliability and} dimensionality

The review of several streams of literature provides a critical foundation of the measures used in this research. Following relevant literature, five measurement scales constitute a hypothetical framework of the current research namely; entrepreneurial attitude, business climate, behavioural factors, subjective norms and entrepreneurial intentions. Empirical findings of the referenced studies confirmed the suitability of these measurement scales. In addition to scale suitability, the adopted scales are quite applicable to the goal of this research and the statements in each scale are clear and easily comprehensible.

All the selected scales were measured using a seven-point Likert scale ranging from strongly agree to strongly disagree. Perceived behavioural factors [5] evaluate students' perception of the university systems to incentivize their intention to entrepreneurial engagement. A total of four statements have been used to measure students' perceived behaviour controls. Using six statements, subjective norms [5] used in this research evaluates students' innate perception of entrepreneurial venturing. This scale measures how students view entrepreneurship. The scale entrepreneurial attitude [5], is used to evaluate students' attitude towards engaging in entrepreneurial ventures based on five statements. We used the scale - business climate [34] to observe the environmental perception impacting start-ups business ventures in the country. The scale uses five statements revolving around tax system, infrastructure, enabling business environment, financial, legal and government support to entrepreneurship ventures in the country. Entrepreneurial intention scale [35] uses five statements to evaluate students' current and future intention to engage in entrepreneurship venture. It also observes how respondents saw off themselves in the course of venturing in start-ups business activities.

The results of the Cronbach's alpha confirm the internal consistency and reliability (i.e. the suitability) of the adopted measurement scales. The details of the reliability of the adopted scales are illustrated below.

TABLE 2. MEASUREMENT SCALES AND CRONBACH'S ALPHA (RELIABILITY)

\begin{tabular}{|l|c|c|}
\hline \multicolumn{1}{|c|}{ Measurement scales } & $\begin{array}{c}\text { Number of } \\
\text { statements }\end{array}$ & $\begin{array}{c}\text { Cronbach's Alpha } \\
\text { (reliability in \%) }\end{array}$ \\
\hline Perceived Behavioural factors & 4 & 0.751 \\
\hline Subjective norms & 6 & 0.901 \\
\hline Entrepreneurial attitude & 5 & 0.689 \\
\hline Business climate & 6 & 0.845 \\
\hline Entrepreneurial intention & 5 & 0.879 \\
\hline
\end{tabular}

\section{DATA ANALYSIS AND RESULTS}

Using IBM SPSS statistical software (version 22), the results of the current study are illustrated through descriptive statistics, graphs, charts and matrices. The first part of the analysis is the sample population of the study. Secondly, the hypothesis testing was done, and the results of the multiple linear regressions are presented.

\section{A. Sample profile and procedure}

A total of hundred and eighty-nine students participated in this research. Out of this number, a hundred and eighty-eight (188) constitute the final number of respondents. This is a convenient representation of the student population of the UTG. Of all the respondents, male students (a total of 98 students) comprise of $52 \%$ and female students (a total of 91 students) make up $48 \%$ of the respondents. A total mean $(m=1.481)$ and standard deviation of $(0.501)$ is shown in the distribution. A significant per cent $(50.8 \%)$ are within the age category of 18-24 years old, while 25-34 years old makeup of $37 \%$, the age category $34-44$ years old makes up of $10.6 \%$ and the smallest proportion of respondents fall within the age category of 45 and above $(2 \%)$. The age category recorded a mean $(m=1.619)$ and a standard deviation (0.716).

Moreover, the classification of respondents in terms of the current level of education at the university composed of a 
bigger per cent of students $(73.5 \%)$ enrolled in the undergraduate programs, followed by a significantly small proportion $(13.8 \%)$ of students enrolled in the professional diploma program of the UTG. High school students (11.6\%) enrolled in the university's access programs makes up of the third among respondents. Only a smaller per cent $(1.1 \%)$ of graduate students enrolled in the various master's degree programs participated in the research. Unfortunately, none of the doctorate $(\mathrm{PhD})$ students participated or completed has been recorded. The summary of the SPSS output of the descriptive statistics of sampling data is shown in the table below.

TABLE 3. DESCRIPTIVE SUMMARY OF THE SAMPLE PROFILE

\begin{tabular}{|c|c|c|c|c|c|}
\hline Sample profile & Category & Frequency & $\begin{array}{l}\text { Valid } \\
\text { percent }\end{array}$ & Mean & $\begin{array}{l}\text { Standard } \\
\text { deviation }\end{array}$ \\
\hline \multirow[t]{3}{*}{ Gender } & Male & 98 & $51.9 \%$ & \multirow[b]{3}{*}{1.481} & \multirow[b]{3}{*}{0.501} \\
\hline & Female & 91 & $48.1 \%$ & & \\
\hline & Total & 189 & $100 \%$ & & \\
\hline \multirow[t]{5}{*}{ Age category } & $18-24$ & 98 & $58.8 \%$ & \multirow[b]{5}{*}{1.619} & \multirow[b]{5}{*}{0.716} \\
\hline & $25-34$ & 71 & $37.6 \%$ & & \\
\hline & $35-44$ & 20 & $10.6 \%$ & & \\
\hline & $45+$ & 2 & $1.1 \%$ & & \\
\hline & Total & 189 & $100 \%$ & & \\
\hline \multirow{6}{*}{ Education } & High School & 22 & $11.6 \%$ & \multirow{6}{*}{2.641} & \multirow{6}{*}{0.697} \\
\hline & $\begin{array}{l}\text { Professional } \\
\text { Diploma }\end{array}$ & 26 & $13.8 \%$ & & \\
\hline & $\begin{array}{l}\text { Undergraduate } \\
\text { (Bachelors) }\end{array}$ & 139 & $73.5 \%$ & & \\
\hline & $\begin{array}{l}\text { Graduate } \\
\text { (master's) }\end{array}$ & 2 & $1.1 \%$ & & \\
\hline & $\mathrm{PhD}$ & 0 & $0 \%$ & & \\
\hline & Total & 189 & $100 \%$ & & \\
\hline
\end{tabular}

\section{B. Descriptive statistics of the scale}

The scales adopted were evaluated by respondents according to the seven-point Likert scale, ranging from strongly disagree $=1$ to strongly agree $=7$. The predetermined sets of questions elicit perceptions on the drivers of students' entrepreneurial intention to engage in start-up and small business ventures. Out of the total respondents recorded, results showed that there exists a deferring opinion of students in their evaluation of each measurement construct; entrepreneurial intention, business climate, subjective norms, perceived behavioural factors and entrepreneurial attitude.

The statistical mean $(\mathrm{m})$ for subjective norms $(m=5.858)$ and entrepreneurial intention $(m=5.405)$ with a standard deviation of (1.224) and (1.479) respectively, were recorded. This confirms that a greater number of respondents are more inclined towards the scale "agree" and "slightly agree" (i.e. $5.00-6.00)$ in their evaluation of the subjective norms and entrepreneurial intention. Respondents demonstrate "neither agree nor disagree" (i.e. $4.00-4.90$ ) in their overall evaluation of "entrepreneurial intention" $(m=4.841)$ and "perceived behavioural factors" $(m=4.425)$ with a standard deviation (1.165) and (1.435) respectively. It could be assumed that respondents are not aware of their entrepreneurial intention and thus may not intentionally exhibit any form of behaviour towards engaging in entrepreneurial ventures. However, respondents evaluated "business climate" $(m=3.623)$ with a standard deviation of (1.379) less favorably compared to other constructs. This means, respondents, evaluated The Gambia's business environment as "slightly disagree" (i.e. 3.00 - 3.90) in their perception of entrepreneurial investment in the country. The table below summarizes the descriptive statistics of the research measurement constructs. MEASUREMENT SCALES

\begin{tabular}{|l|l|l|l|l|l|}
\hline Measures & N & Minimum & Maximum & Mean & $\begin{array}{l}\text { Std. } \\
\text { Deviation }\end{array}$ \\
\hline Entrepreneurial intention & 188 & 1.00 & 7.00 & 5.4053 & 1.47976 \\
\hline Business climate & 188 & 1.00 & 7.00 & 3.6235 & 1.37927 \\
\hline Subjective norms & 188 & 1.00 & 7.00 & 5.8582 & 1.22413 \\
\hline Perceived behavioral factors & 188 & 1.25 & 7.00 & 4.4255 & 1.43501 \\
\hline Entrepreneurial attitude & 188 & 1.00 & 7.00 & 4.8415 & 1.16572 \\
\hline Valid N (listwise) & 188 & - & - & - & - \\
\hline
\end{tabular}

Furthermore, we observe the relationship between gender and measurement constructs. Results of the Pearson Chisquare tests (using the 2-tailed) show that there is no significant difference between Male and Female Students in their evaluation of the constructs - entrepreneurial attitude (sig. $=0.451, p>0.05)$, perceived behavioral factors $($ sig $=$ $0.627, p>0.05$ ), subjective norms ( $\operatorname{sig}=0.456, p>0.05$ ), business climate $(\operatorname{sig}=0.362, p>0.05)$ and entrepreneurial intention ( $\operatorname{sig}=0.485, p>0.5)$. Similarly, we also observe the difference of variance (ANOVA) between levels of education and the constructs. The results of one-way ANOVA show a significant variation in students' evaluation of entrepreneurial intention and their respective level of education $(f$-test $=2.53$, sig $=0.05)$. However, no significant difference (sig. $>0.05$ ) between students' level of education and their evaluation of the other constructs has been observed.

\section{Hypothesis testing}

Following best research practice, before we proceed with a linear regression test, a test for multicollinearity was performed on the model. Results of the ANOVA (f-test $=$ 49.983, sig. $=0.00$ ) show that there are no such multicollinearity issues in the model determination. Moreover, we double-checked multicollinearity issues through collinearity diagnostics, to observe if values (VIF) are less than 4 (which mean no multi colinearity issues) were observed. Thus, the results of the collinearity diagnostics find no extreme cases on the model output. The summary of the model indicates that model is a good fit for prediction of independent variables on the dependent variable and hence the quality of multiple correlation coefficient $(R=0.72 \%)$ and model determination $\left(R^{2} 0.52 \%\right)$ are enough. The result of the ANOVA (see table 5) indicate that the model is a good fit of the data in this study, where $F$ $(4,183)=49.983)$ and $($ sig. $<0.000)$ are observed.

Using unstandardized coefficients, we observe how much the dependent variable (entrepreneurial intention) varies with any change in any dependent variable when other independent variables are constant. For example, a year change in either Entrepreneurial attitude $(B=0.526)$, Subjective norms $(B=0.483)$ or business climate $(B=-$ 0.022) will caused a significant change on students' entrepreneurial intention, hence (sig. < 0.001). Among all independent variables, only the business climate has a severe negative effect on entrepreneurial intention of our respondents. However, perceived behavioural factors $(B=$ 0.086) has recorded no significant effect on the entrepreneurial intention in our data. Multiple regression was run to predict entrepreneurial intention from perceived behavioural factors, entrepreneurial attitude, subjective norms and business climate. All the variables are statistically significant and thus predicted entrepreneurial intention, $\left(F(4,982)=183\right.$, sig. $\left.<0.05, R^{2}=0.522\right)$. 
However, perceived behavioural factors failed to show any statistically significant prediction on the model (sig. $>0.05$ ). Based on the multiple regression results, $\mathrm{H} 2, \mathrm{H} 3$, and $\mathrm{H} 4$ are supported in our research. However, H1 could not be substantiated according to our data. Therefore, the general form of the equation to predict our independent variables in relations to output variable is predicted based on coefficients of the regressions (see Table 7). Entrepreneurial intention =$0.276+(0.526 \mathrm{x}$ Entrepreneurial attitude $)+(0.086 \mathrm{x}$ Perceived behavioral factors $)+(0.483 \times$ Subjective norms $)-$ (0.022 x Business climate). Below, Table 5 is the SPSS output of the multiple regression.

Table 5. SPSS OUTPUTS ON THE RESEARCH MODEL

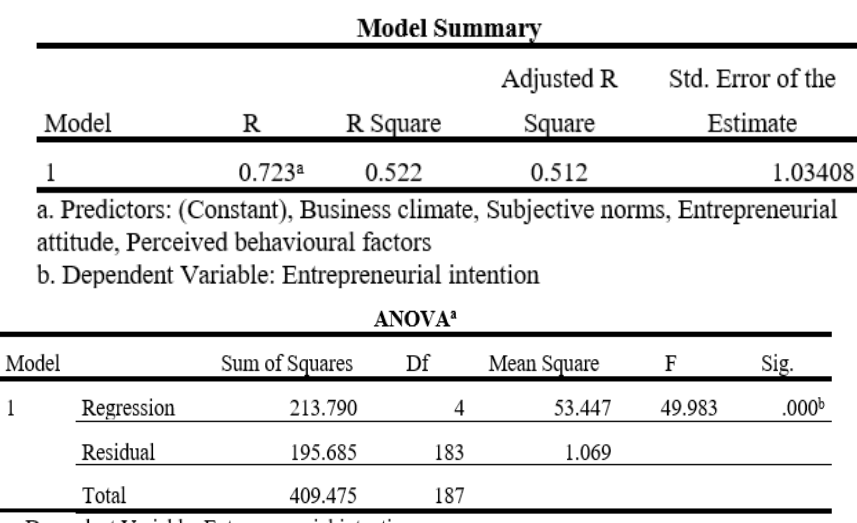

a. Dependent Variable: Entrepreneurial intention

b. Predictors: (Constant), Business climate, Subjective norms, Entrepreneurial attitude, Perceived behavioral factors

\begin{tabular}{|c|c|c|c|c|c|c|c|}
\hline \multirow[b]{3}{*}{ Model } & \multicolumn{3}{|c|}{ Coefficients $^{\mathrm{a}}$} & \multirow[b]{3}{*}{$t$} & \multirow[b]{3}{*}{ Sig. } & & \\
\hline & \multicolumn{2}{|c|}{$\begin{array}{l}\text { Unstandardize } \\
\text { d Coefficients }\end{array}$} & \multirow{2}{*}{$\begin{array}{c}\text { Standardized } \\
\text { Coefficients } \\
\text { Beta }\end{array}$} & & & \multicolumn{2}{|c|}{$\begin{array}{c}95.0 \% \\
\text { Confidence } \\
\text { Interval for B }\end{array}$} \\
\hline & $\mathrm{B}$ & \begin{tabular}{|c|} 
Std. \\
Error
\end{tabular} & & & & \begin{tabular}{l|} 
Lower \\
Bound
\end{tabular} & \begin{tabular}{|l|} 
Upper \\
Bound \\
\end{tabular} \\
\hline 1 (Constant) & -.276 & .416 & & -.663 & .508 & -1.098 & .546 \\
\hline Entrepreneurial attitude & .526 & .077 & .414 & 6.852 & .000 & .374 & .677 \\
\hline Perceived behavioral factors & .086 & .063 & .084 & 1.365 & .174 & -.038 & .211 \\
\hline Subjective norms & .483 & .070 & .400 & 6.858 & .000 & .344 & .622 \\
\hline Business climate & -.022 & .063 & -.020 & -.343 & .0432 & - -146 & .102 \\
\hline
\end{tabular}

We further run a test to ascertain if there is any effect of respondents' level of education on the model. However, no statistical significance was observed in the results of the Chi-Square tests according to gender, level of education and age category ( sig. $>0.05)$

\section{DISCUSSION OF RESULTS}

This research examines the entrepreneurial intention of students at the University of the Gambia. Our results show that the degree of students' intention to engage in entrepreneurial ventures varies, and thus in line with several previous studies (e.g., [40], [41]). Some of these entrepreneurial ventures include investment in start-ups, informal small business trading, and joint ventures or partnership business. The formation of students or new graduates into corporate ventures is largely rare among these segments. Scholars suggest that individual self-efficacy influence their behavioural intention to engage in entrepreneurship [28]. According to these scholars "Individual self-efficacy, is defined as a person's belief in his or her capability to perform a task, influences the development of both entrepreneurial Intentions and actions or behaviours." (p. 63). Such personal traits are deterministic of an individual's career choice and future development. This orientation nurtures cognitive process involved in the formation of entrepreneurial intentions and actions [28].

Our research finds some interesting results: the entrepreneurial intention of university students is explained by various factors. Some of these factors include the business climate of the country. A result of our study is in line with several pieces of research (e.g., [28]). A significant number of students $20 \%$ of respondents believe that they will most likely engage in entrepreneurial ventures depending on the dynamics of the business environment in the country. For example, some of the salient concerns that are critical to this decision are the tax conditions, infrastructure (roads, electricity, etc.), credit facilities or start-up finance, and stable political economy. In fact, for the general conduct of industrial markets, some of these factors are major drivers of business investment decisions. Suggest that high entrepreneurial attitude including selfesteem cognition and achievement conation invoke entrepreneurial desire to engage in a business venture [31].

Moreover, respondents' evaluation of entrepreneurial attitude is a critical feature of their intention to engage in an entrepreneurial venture. The current confirms this. This evaluates students' intention based on their experience and opinion on attitudes of both successful and failing entrepreneurs. Studies opined that successful entrepreneurs have distinct personal and behavioural traits. These observable traits are signals yet-to-be individual seeking to join entrepreneurial terrain. Therefore, more interactions with distinct entrepreneurs may trigger large followers to form entrepreneurial intention decision. Thus, the Universities must expose students to more intensive, practice-oriented entrepreneurship courses to invoke interest. Moreover, mentorship, coaching and interaction with ardent and successful entrepreneurs will further stimulate entrepreneurship awareness and interest. Such strategies would invoke students' motivation and intention to engage in entrepreneurial practices [28]. Our result thus confirms these practices.

The subjective norms were evaluated as fundamental to students' entrepreneurial intention decision. This result is supported by other studies in the past (e.g. [40], [41]). The general norms associated with entrepreneurship such as "being your own boss" and "a key contributor to employment provision" makes this assessment a relevant factor among university students. These students seek to help develop themselves through financial independence and their contribution to the broader economy. Studies support the view that academically vibrant graduates of the universities enjoy their autonomy associated with entrepreneurship business ownership.

\section{CONCLUSION AND IMPLICATION}

This study examined the drivers of entrepreneurial intention among students of the University of the Gambia. Using the theory of planned behaviour and entrepreneurial intention model, our results confirm the significant role of the business climate, entrepreneurial attitude and subjective norms on students' intention to engage in entrepreneurship ventures. The findings of our study provided distinctive implications for the government of the Gambia, policymakers, and educational institutions. The government must ensure that the right business climate is obtained to stimulate the growth of the business industry and further 
inspire the entrance of new and innovative young graduates into the entrepreneurial field. Part of this initiative is the promulgation of regulations, policies to foster the provision of low cost, interest-free, and grants to start-ups, emerging companies and corporations. Thirdly, a flexible tax system must be instituted to lower the tax burden on start-ups, especially young graduates seeking to start businesses.

The few courses offered at the UTG that introduces students to the application of business include entrepreneurship and small business management courses. By extension, the provision of entrepreneurial hubs to serve as an incubation Centre for budding and emerging entrepreneurs in the university campus will motivate and inspire students into entrepreneurship ventures. However, single entrepreneurship subject/course currently offered at the UTG could not maximize the behavioural intentions of students to engage in entrepreneurial ventures. A robust entrepreneurial environment should be created starting with a dedicated department or faculty that is responsible for entrepreneurship education (rules, policies, procedures, attitudes of lecturers, etc.). The lack of which will inhibit the entrepreneurial spirit of students. Furthermore, a dedicated faculty would foster business management education and research activities specifically meant to engender entrepreneurship, is required to invigorate and nurture the creative talents of young minds. Meanwhile, Lope Pihie and Bagheri [2] suggest that these practices direct positive signals to the entrepreneurial intention of young students through learning and social interaction, and where possible, in-campus trade fares among students.

We also suggest that both the ministries of Basic and Higher Education engage relevant stakeholders to craft and implement a National entrepreneurship education curriculum. By all means, this should be prioritized by the respective ministries (precisely, higher, tertiary, and basic education ministries) to help mitigate the impact of unemployment on the youthful population, especially among graduates from the universities and other tertiary education institutions. Besides, management and technical support programs could be sought to help strengthen the growth of start-ups and emerging firms.

Thus, an entrepreneurship hub or center should be created to develop and sustain an innovation and creativity ecosystem of the UTG. Entrepreneurship training and education facilities dedicated to fostering change in mindset focusing on instilling and modifying behavioural, cognition and self-esteem necessary for positive entrepreneurial attitude are critical components of growth in entrepreneurial intention in many universities.

This study has faced some noticeable limitations which include a need for a larger population, such as a nationwide survey of student entrepreneurial intention and attitude in The Gambia could be more representative for generalization of the findings.

Future research agenda could explore several other constructs such as self-esteem, vocational entrepreneurship training programs, experimental learning, mentorship and real-time in-campus and off-campus trade fare. These issues would further advance the theory of entrepreneurship education and practice.

\section{ACKNOWLEDGMENT}

We are very appreciative of the invaluable advice of the peer reviewers at the EJBMR. We are also grateful to the
University of The Gambia Students' Union (2019-2020) for their support during this research.

\section{Declaration of Conflicting Interests}

The authors declared no potential conflicts of interest concerning the research, authorship, and/or publication of this article.

\section{Funding}

The authors received no financial support for the research, authorship, and/or publication of this article.

\section{REFERENCES}

[1] A. Gird, and J.J. Bagraim (2008). The theory of planned behaviour as predictor of entrepreneurial intent amongst final-year university students. South African Journal of Psychology, 38(4), 711-724.

[2] Z. L. Pihie, \& A. Bagheri (2011). Malay secondary school students' entrepreneurial attitude orientation and entrepreneurial self-efficacy: A descriptive study. Journal of Applied Sciences, 11(2), 316-322.

[3] V. Souitaris, S. Zerbinati, \& A. Al-Laham, (2007). Do entrepreneurship programmes raise entrepreneurial intention of science and engineering students? The effect of learning, inspiration and resources. Journal of Business venturing, 22(4), 566-591.

[4] A. Tkachev, \& L. Kolvereid (2010). Self-Employment Intentions among Russian Students. Entrepreneurship \& Regional Development: An International Journal. 11. 269-280. 10.1080/089856299283209.

[5] I. Ajzen (1991). The theory of planned behavior. Organizational behavior and human decision processes, 50(2), pp.179-211.

[6] I. Ajzen and M. Fishbein (1980). Understanding Attitudes and Predicting Social Behaviour (Englewood Cliffs, Prentice-Hall).

[7] B. H. Sheppard, J. Hartwick, \& P. R. Warshaw (1988). The theory of reasoned action: A meta-analysis of past research with recommendations for modifications and future research. Journal of Consumer Research, 15(3), 325-343. https://doi.org/10.1086/209170.

[8] L. Kolvereid (1996). Prediction of Employment Status Choice Intentions. Entrepreneurship: Theory and Practice 21(1), 47-58.

[9] J. Audet (2002). A longitudinal study of the entrepreneurial intentions of university student, Academy of Entrepreneurship Journal VL-10.

[10] E. Autio, H. R. Keeley, M. Klofsten, G C. G. Parker and M. Hay (2001). Entrepreneurial intent among students in Scandinavia and in the USA. Enterprise and Innovation Management Studies, 2(2), 145160 .

[11] A. Fayolle, B. Gailly \& N. Lassas-Clerc (2006). Assessing the impact of entrepreneurship education programmes: a new methodology. Journal of European industrial training.

[12] M. Van Gelderen, M. Brand, M. Van Praag, W. Bodewes, E. Poutsma, \& A. Van Gils (2008). Explaining entrepreneurial intentions by means of the theory of planned behaviour. Career development international.

[13] N. F., Krueger Jr, M. D. Reilly, \& A. L. Carsrud (2000). Competing models of entrepreneurial intentions. Journal of business venturing, 15(5-6), 411-432.

[14] J. M. Veciana, M. Aponte, \& D. Urbano (2005). University students' attitudes towards entrepreneurship: A two countries comparison. The International Entrepreneurship and Management Journal, 1(2), 165182.

[15] N. F. Krueger, (2017). Entrepreneurial intentions are dead: Long live entrepreneurial intentions. In Revisiting the entrepreneurial mind (pp. 13-34). Springer, Cham.

[16] Thompson (2009). Individual entrepreneurial intent: Construct clarification and development of an internationally reliable metric. Entrepreneurship theory and practice, 33(3), 669-694.

[17] S. Shane, \& S. Venkataraman (2000). The promise of entrepreneurship as a field of research. Academy of management review, 25(1), 217-226.

[18] A. A. Teixeira, \& R. P. Forte, (2009). Unbounding entrepreneurial intents of university students: a multidisciplinary perspective (No. 322). Universidade do Porto, Faculdade de Economia do Porto.

[19] The new public mourning. Handbook of bereavement research and practice: 21 st century perspectives (pp. 241-262). T. Walter (2008a).

[20] S. Cromie (2000). Assessing entrepreneurial inclinations: Some approaches and empirical evidence. European journal of work and organizational psychology, 9(1), 7-30.

[21] U. Fueglistaller, F. Halter, H. Klandt, "Die unternehmerische Kraft von Studierenden imnternationalen Vergleich - Evaluation eines 
Untersuchungsrahmens. In: Fueglistaller, U./ Volery, T.Weber, W. (Eds.): Understanding the Regulatory Climate of Entrepreneurship and SMEs. Conference Proceedings Rencontres de St-Gall (2006), Wildhaus.

[22] C. H. Matthews, \& S. B. Moser (1996). A longitudinal investigation of the impact of family background. Journal of small business management, 34(2), 29-43. [33].

[23] Walter, T. (2008b). The presence of the dead in society. In Conference on Death \& Dying in.

[24] N. F. Krueger, \& A. L. Carsrud, (1993). Entrepreneurial intentions: Applying the theory of planned behaviour. Entrepreneurship \& Regional Development, 5(4), 315-330.

[25] A. B. Krueger (2003). Economic considerations and class size. The Economic Journal, 113(485), F34-F63.

[26] B. Bird (1988). Implementing entrepreneurial ideas: The case for intention. Academy of management Review, 13(3), 442-453.

[27] A. Bandura, Social foundations of thought and action. Englewood Cliffs, NJ, 1986.

[28] N. G. Boyd and G. S. Vozikis, (1994). The influence of self-efficacy on the development of entrepreneurial intentions and actions. Entrepreneurship theory and practice, 18(4), 63-77.

[29] L. Kolvereid (1996). Prediction of Employment Status Choice Intentions. Entrepreneurship: Theory and Practice 21(1), 47-58.

[30] M.S. Kim, \& J. E. Hunter (1993). Relationships among attitudes, behavioral intentions, and behavior: A meta-analysis of past research, part 2. Communication research, 20(3), 331-364.

[31] I. Ajzen (1987). Attitudes, traits, and actions: Dispositional prediction of behaviour in personality and social psychology, Advances in Experimental Social Psychology, 20, pp. 1-63.

[32] L.B. Ceesay (2017). Consumer-brand Association: Determinants of Consumer Bank Switching Intention, Case of The Gambia Retail Banking Sector. Journal of Business \& Financial Affairs, 6(4), 1-8.

[33] L.W. Saidykhan, \& L.B. Ceesay (2020). Quality of Work-Life Among Employees of The University of The Gambia. Arch. Bus. Res. 8, 230-248. https://doi.org/10.14738/abr.83.7920.

[34] F. Liñán, \& Y. W. Chen (2009). Development and cross-cultural application of a specific instrument to measure entrepreneurial intentions. Entrepreneurship theory and practice, 33(3), 593-617.

[35] Abidullah, "the Impact of Entrepreneurship Training Program on Russian Students' Intention towards Entrepreneurship. In Innovation Management, Entrepreneurship and Sustainability (IMES 2018) (pp. 18-25). Vysoká škola ekonomická v Praze.

[36] I. Ajzen, (1987). Attitudes, traits, and actions: Dispositional prediction of behavior in personality and social psychology. In Advances in experimental social psychology (Vol. 20, pp. 1-63). Academic Press.

[37] B.H. Boar, (1999). Attitudes, Personality, and Behavior. The Dorsey Press. Chicago.

[38] I. Ajzen, and M. Fishbein (1980). Understanding attitudes and predicting social behavior.

[39] J. Audet (2002). A longitudinal study of the entrepreneurial intentions of university students. Academy of Entrepreneurship Journal, Vol.10, No. (1 et 2), pp. (3-16).

[40] M. N. M. Shariff, \& M. B. Saud (2009). An attitude approach to the prediction of entrepreneurship on students at institution of higher learning in Malaysia. International Journal of Business and Management, 4(4), 129-135.

[41] E. R. Mentoor \& C. Friedrich (2007). Is entrepreneurial education at South African universities successful? An empirical example. Industry and Higher Education, 21(3), 221-232.

[42] B. Bird, and G. P. West (1998). Time and entrepreneurship. Entrepreneurship theory and practice, 22(2), 5-9.

[43] M. Conner and C.J. Armitage (1998). Extending the theory of planned behavior: A review and avenues for further research. Journal of applied social psychology, 28(15), 1429-1464.

[44] M. Fishbein \& I. Ajzen (1975). Belief, Attitude, Intention and Behaviour: An Introduction to Theory and Research. IN ADDISONWESLEY READING. $M$. (Ed.).

[45] N. F. Krueger, \& J. Kickul, "So you thought the intentions model was simple? Cognitive style and the specification of entrepreneurial intentions models. Cognitive style and the specification of entrepreneurial intentions models (January 24, 2006).

[46] B. H. Sheppard, J. Hartwick, \& P. R. Warshaw, (1988). The theory of reasoned action: A meta-analysis of past research with recommendations for modifications and future research. Journal of consumer research, 15(3), 325-343.

[47] A. Tkachev \& L. Kolvereid (1999). Self-employment intentions among Russian students. Entrepreneurship \& Regional Development, 11(3), 269-280.

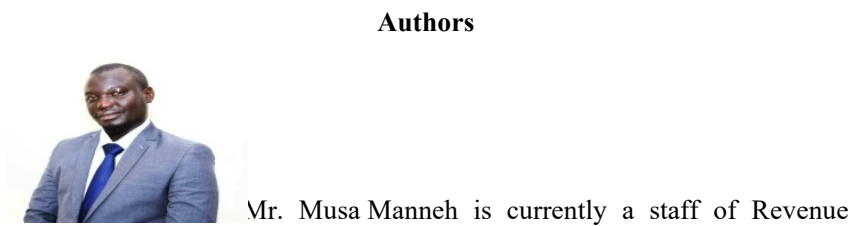
Authority. He is also an adjunct lecturer at the School of Business and Public Administration of the University of the Gambia. His research interest relates to energy business, and social entrepreneurship.

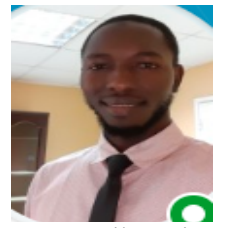

Mr. Ismaila Bojang is an adjunct lecturer at the University of the Gambia, School of Business \&amp; Public Administration in Kanifing, The Gambia. His research interests are e-commerce, digital marketing, techentrepreneurship, logistics and supply chain.

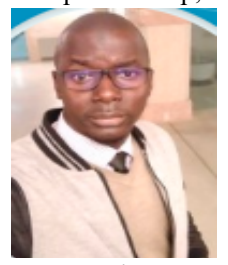

Mr. Lamin B. Ceesay is a staff of the University of the Gambia, and currently pursuing his $\mathrm{PhD}$ in Management at University Verona, Italy. Mr. Ceesay's research interest revolves around Consumer research, Interorganizational relationship and Innovation management.

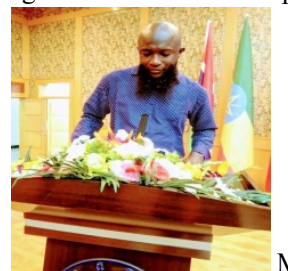

University of Mr. Sama Jawneh is a full-time instructor at the Administration. His research interest is in the areas of Marketing and Consumer research. 